\title{
Insect Damage to Sweet Corn Hybrids in the South Atlantic European Coast
}

\author{
R.A. Malvar, ${ }^{1}$ P. Revilla, P. Velasco, M.E. Cartea, and A. Ordás \\ Misión Biológica de Galicia, Spanish Councilfor Scientific Research, Apartado 28,36080 Pontevedra, Spain
}

\begin{abstract}
AdDitional INDEX words. maize, Zea mays, Sesamia nonagrioides, Ostrinia nubilalis, maturity, planting date
Abstract. The pink stem borer (PSB) (Sesamia nonagrioides Lefebvre) and the European corn borer (ECB) (Ostrinia nubilalis Hübner) are the major insect pests of corn (Zea mays L.) in Mediterranean countries, although larvae of other insects can also cause damage. The objective of this research was to evaluate the effect of sweet corn hybrids, planting time, and environment on damage by various insects. Data were recorded on the number of larvae of each of the aforementioned pests and damage produced in the ear 20 days after pollination and in the ear and stem when plants were dry. PSB was the most abundant pest, followed by ECB. Other insects, such as Mythimna unipuncta (Haworth) and Helicoverpa armigera (Hübner) were rarely found in sweet corn plants. ECB was constant over time, PSB had larger seasonal variation, and $M$. unipuncta and $H$. armigera were highly variable over time. There were significant differences among planting dates and growing cycles for damage traits in each environment. Interactions among hybrids, planting dates, and environments were significant. Dry ears were damaged more than fresh ears and stems had more larvae than ears. The economic value of the crop was seriously affected because most fresh ears had some damage, and seed production would be severely affected by PSB.
\end{abstract}

The main pests of corn (Zea mays) in Mediterranean countries are the pink stem borer (PSB) (Sesamia nonagrioides) and the European corn borer (ECB) (Ostrinia nubilalis), although some other pests are present (Cordero et al., 1998). In northwest Spain, PSB is more abundant and causes more damage than ECB (Cartea et al., 1994; Malvar et al., 1993; Velasco et al., 1999a). The abundance of both species could be regulated by similar factors (Cordero et al., 1998). High occurrence of PSB attack has been reported in Morocco (Lespès and Jourdan, 1940), Spain (Alfaro, 1955), France (Anglade, 1961), Greece (Tsitsipis et al., 1987), and Israel (Melamed-Madjar and Tam, 1980).

Attack by borers on field corn is being studied extensively (Abel et al., 1995, 2000; Butrón et al., 1998; Cartea et al., 2001). Previously published results suggest that larvae of the first generation rarely attack corn (Anglade, 1972), but larvae of the second generation colonize most plants by the end of the summer (Cordero et al., 1998). Attack on sweet corn has special consequences, mainly because this crop is harvested early in the season, around $20 \mathrm{~d}$ after pollination, and minor damage or insect presence is not allowed in a product used for human consumption.

Dicke and Guthrie (1988) mention the corn earworm Heliothis zea. Boddie, synonym of Helicoverpa zea Boddie, as a pest of corn in the United States. Helicoverpa armigera is not an insect to be concerned with in Spain although it appears in sweet corn depending on the year. No previous publications mention Mythimna unipuncta as a corn pest, though observations indicate that some leaf and silk feeding is caused by M. unipuncta some years in northwestern Spain. Cordero et al. (1998) reported that great numbers of adults of this species are found in pheromone traps for PSB in northwestern Spain.

Based on results with two field corn and three sweet corn hybrids, Jarvis (1988) concluded that field corn hybrids are more resistant than sweet corn hybrids to ECB. Velasco et al. (1999a) evaluated 28 sweet corn inbreds and four field corn resistant inbreds under PSB infestation and the most resistant sweet corn inbreds did not differ significantly from the most resistant field

Received for publication 20 Sept. 2001. Accepted for publication 4 Apr. 2002. This research was supported by the Xunta de Galicia (Project Cod. XUGA 40301B98) and Excma. Diputación Provincial de Pontevedra, Spain.

${ }^{1}$ Corresponding author; email: rmalvar@mbg.cesga.es. corn inbreds. Sweet corn genotypes bred from crosses involving field corn in their pedigree seemed to be more resistant than sweet corn genotypes unrelated to field corn (Velasco et al., 1999b).

Besides genetic factors, plant age and environment may affect the attack of corn borers (Gardner et al., 2001). Corn borer attack is less important for early than for late-maturing corn for both ECB (Dicke and Guthrie, 1988) and PSB (Malvar et al., 1993) probably because borers prefer younger corn (Abedon and Tracy, 1996). Also, late plantings were more severely attacked than early plantings of both field (Cartea et al., 1994) and sweet corn (Velasco et al., 1999a, 1999b) because maize planted later is at a more attractive stage for corn borers when these reach its maximum abundance.

The design of a sweet corn breeding program for resistance to pests requires knowledge of occurrence and importance of diverse pests under the local growing conditions. The objective of this research was to evaluate the effect of sweet corn hybrids, planting time, and environment on damage by various insects.

\section{Materials and Methods}

Six sweet corn hybrids having different growing cycles were used for this research (Table 1). The hybrids were planted in 1996, 1997 , and 1998 at Pontevedra (lat. $42^{\circ} 24^{\prime} \mathrm{N}$, long. $8^{\circ} 38^{\prime} \mathrm{W}, 20 \mathrm{~m}$ above sea level) and Barrantes (lat. $42^{\circ} 30^{\prime} \mathrm{N}$, long. $8^{\circ} 46^{\prime} \mathrm{W}, 50 \mathrm{~m}$ above sea level) in northwestern Spain. Both locations have a humid climate with annual rainfall of $\approx 1600 \mathrm{~mm}$. Previous experiments have shown that both locations have a high natural infestation of corn borer, Barrantes being the most heavily infested (Cordero et al., 1998).

Each year, the six hybrids were planted early and late, according to the following schedule: in 1996 Barrantes was planted on 7 May and 11 June and Pontevedra on 15 May and 5 June; in 1997 Barrantes on 2May and 24 June and Pontevedra on 13 May and 19June; and in 1998, Barrantes on 28 May and26June and Pontevedra on 15 May and 17 June. The experiment was arranged as a randomized complete block design with four replications. Each two-row experimental plot consisted of 15 hills per row with two kernels per hill. Rows were spaced $0.80 \mathrm{~m}$ apart and hills $0.21 \mathrm{~m}$. Hills were thinned to one plant to achieve a final plant density of $\approx 60,000$ plants/ha. 
Table 1. Sweet corn hybrids planted early and late during 3 years in two northwestern Spanish locations, their pedigree, growing cycle, and origin.

\begin{tabular}{lccc}
\hline \hline Hybrid & Pedigree & Growing cycle & Origin \\
\hline Earlivee & V663xV642 & Extra-early & Kerr (1981a) \\
Marcross & C13xC6 & Early & Singleton (1948) \\
Goldenvee & I5492xCO108 & Early midseason & Kerr (1979a) \\
Tablevee & V679xV576 & Midseason & Kerr (1979b) \\
Iochief & I5125xI453 & Late midseason & Smith (1955) \\
Flavorvee & V7726xI5177 & Late & Kerr (1981b) \\
\hline
\end{tabular}

The ears from half of the plants of each experimental plot were harvested at eating stage, $20 \mathrm{~d}$ after pollination. The remaining ears were harvested when they were dry to estimate potential damage in seed production. Data recorded on fresh and dry ears per plot were: general appearance of the ear $(1=$ nondamaged kernels, $2=$ up to $20 \%$ of kernels damaged, $3=21 \%$ to $40 \%$ of kernels damaged, $4=41 \%$ to $60 \%$ of kernels damaged, and $5>$ $61 \%$ of kernels damaged), percentage of ears with damaged husks, damaged grain, damaged cob, damaged shank, and without damage, and number of larvae of PSB, ECB, H. armigera, and $M$. unipuncta per ear. The number of $H$. armigera larvae per ear was recorded only in 1998 because this species rarely appeared other years. Finally, five dry stems per plot were dissected to measure tunnel length and to count numbers of larvae.

Individual and combined analyses of variance were conducted for all traits, except for number of larvae, for each planting date and environment. Plantings and hybrids were considered fixed, while environments and replications were considered random effects. Each year-location combination was considered an environment. All analyses were performed using GLM procedures of SAS (SAS Inst., Inc., 1996). Means were separated using Fisher's protected least significant difference (LSD) at $P=0.05$.

\section{Results and Discussion}

For fresh ears, environments had no significant effects. Planting dates affected significantly the general appearance of the ear, proportion of ears with damaged husks and with damaged grain, and differences among hybrids were not significant (data not presented). There were significant environment $\times$ planting date interactions for most traits, planting date $\times$ hybrid interactions for half of the traits, and environment $\times$ planting date $\times$ hybrid interactions for all traits. Therefore, planting date was the only significant factor for corn borer damage to fresh sweet corn ears. However, effects of planting dates depend on environments and hybrids because interactions among these effects were significant.

For dry ears, environments were significantly different for half of the traits and planting dates for all traits (data not presented). Significant interactions were detected for environment $\times$ planting date for general appearance of the ear, environment $\times$ hybrid interaction for ears with damaged husks, and environment $\times$ planting date $\times$ hybrid interaction for ears with damaged cobs and shanks. Therefore, corn borer damage to dry sweet corn ears was affected mainly by planting dates, but also by environments. Hybrids had no significant effect for ear damage traits, but there were significant interactions with environments and planting dates.

Tunnel length in dry stems varied significantly among hybrids and had significant environment $\times$ planting date and environment $\times$ planting date $\times$ hybrid interactions. A possible explanation of the different performance of ears and stems might be that PSB, the main pest, feeds preferentially on stems and is affected so strongly by differences among hybrids that other effects are masked.

Differences among hybrids were significant for few traits in each environment, except for Barrantes in 1997, where hybrids differed significantly for five of the six traits. The planting date $\times$ hybrid interaction was significant for most traits in Barrantes and for few traits in Pontevedra. Using general appearance as an

Table 2. Means for six traits recorded on dry ears of six sweet corn hybrids evaluated in six environments and two planting dates under high natural infestation conditions.

\begin{tabular}{|c|c|c|c|c|c|c|}
\hline Entry & $\begin{array}{c}\text { General } \\
\text { appearance } \\
\text { of ear }\end{array}$ & $\begin{array}{c}\text { Ears with } \\
\text { damaged } \\
\text { husks }\end{array}$ & $\begin{array}{c}\text { Ears with } \\
\text { damaged } \\
\text { grain }\end{array}$ & $\begin{array}{c}\text { Ears with } \\
\text { damaged } \\
\text { cob }\end{array}$ & $\begin{array}{c}\text { Ears with } \\
\text { damaged } \\
\text { shank }\end{array}$ & $\begin{array}{c}\text { Ears } \\
\text { without } \\
\text { damage }\end{array}$ \\
\hline \multicolumn{7}{|l|}{ Environment } \\
\hline Barrantes 96 & $2.99 \mathrm{a}^{\mathrm{y}}$ & $64 \mathrm{a}$ & $76 \mathrm{a}$ & $59 \mathrm{~b}$ & $67 a b$ & $18 \mathrm{~b}$ \\
\hline Barrantes 97 & $2.84 \mathrm{a}$ & $63 \mathrm{a}$ & $72 \mathrm{a}$ & $58 \mathrm{~b}$ & $60 \mathrm{~b}$ & $16 \mathrm{~b}$ \\
\hline Barrantes 98 & $3.63 \mathrm{a}$ & $90 \mathrm{a}$ & $88 \mathrm{a}$ & $68 \mathrm{a}$ & $72 \mathrm{a}$ & $4 \mathrm{c}$ \\
\hline Pontevedra 97 & $1.87 \mathrm{a}$ & $32 \mathrm{a}$ & $45 \mathrm{a}$ & $30 \mathrm{c}$ & $31 \mathrm{~d}$ & $41 \mathrm{a}$ \\
\hline Pontevedra 98 & $2.12 \mathrm{a}$ & $63 \mathrm{a}$ & $66 \mathrm{a}$ & $19 \mathrm{~d}$ & $26 \mathrm{~d}$ & $22 \mathrm{~b}$ \\
\hline \multicolumn{7}{|l|}{ Planting dates } \\
\hline Early planting & $2.13 \mathrm{~b}$ & $44 \mathrm{~b}$ & $56 \mathrm{~b}$ & $29 \mathrm{~b}$ & $36 \mathrm{~b}$ & $28 \mathrm{a}$ \\
\hline Late planting & $3.11 \mathrm{a}$ & $67 \mathrm{a}$ & $82 \mathrm{a}$ & $62 \mathrm{a}$ & $66 \mathrm{a}$ & $11 \mathrm{~b}$ \\
\hline
\end{tabular}


Table 3. Means of tunnel length $(\mathrm{cm})$ and mean number of $S$. nonagrioides (PSB) and $O$. nubilalis (ECB) larvae per dry stem, from six sweet corn hybrids evaluated in six environments and two planting dates under high natural infestation conditions.

\begin{tabular}{|c|c|c|c|c|c|c|}
\hline \multirow[b]{2}{*}{ Entry } & \multicolumn{6}{|c|}{ Growing cycle } \\
\hline & Extra-early & Early & Early midseason & Midseason & Late midseason & Late \\
\hline Barrantes 96 & $19.1 \mathrm{~b}^{\mathrm{z}}$ & $17.6 \mathrm{~b}$ & $24.4 \mathrm{~b}$ & $28.8 \mathrm{~b}$ & $41.6 \mathrm{a}$ & $46.6 \mathrm{a}$ \\
\hline Barrantes 98 & $30.6 \mathrm{ab}$ & $35.3 \mathrm{ab}$ & $33.6 \mathrm{ab}$ & $--{ }^{\mathrm{y}}$ & $27.4 \mathrm{~b}$ & $38.9 \mathrm{a}$ \\
\hline Pontevedra 96 & $39.9 \mathrm{~b}$ & $35.4 \mathrm{~b}$ & $43.4 \mathrm{~b}$ & $41.7 \mathrm{~b}$ & $46.1 \mathrm{~b}$ & $67.4 \mathrm{a}$ \\
\hline Pontevedra 97 & $10.3 \mathrm{a}$ & $12.6 \mathrm{a}$ & $14.4 \mathrm{a}$ & $15.5 \mathrm{a}$ & $16.5 \mathrm{a}$ & $16.6 \mathrm{a}$ \\
\hline Mean number of ECB larvae & $0.52 \mathrm{~b}$ & $0.58 \mathrm{~b}$ & $0.54 \mathrm{~b}$ & $0.62 \mathrm{ab}$ & $0.77 \mathrm{ab}$ & $1.03 \mathrm{a}$ \\
\hline
\end{tabular}

${ }^{\mathrm{z}}$ Mean separation among growing cycles, within rows by Fisher's protected LSD at $P<0.05$.

${ }^{\mathrm{y}}$ Missing data.

indicator of damage, fresh ears were more damaged in Barrantes (1.84) than in Pontevedra (1.38) and late plantings (1.89) more damaged than early plantings (1.33). Damage, measured as general appearance, was higher in Barrantes in 1998 (2.28) and lowest in Pontevedra in 1996 (1.24). Velasco et al. (1999a) and Butrón et al. (1998) found that damage-related traits are highly correlated and that general appearance of the ear is a good indicator of damage.

Dry ears were damaged to a greater extend than fresh ears, particularly in Barrantes, where the late planting had most of the ears damaged in 1998 (Table 2). This high level of infestation in dry plants has been reported previously by Cordero et al. (1998). The comparison of planting dates for dry ear damage (Table 2) followed a similar pattern as for fresh ears. Again ears from early plantings suffered less corn borer damage than from late plantings (Table 2). Generally, ears and stems were more damaged when planted late than when planted early.

Tunnel length and number of PSB larvae in stems increased from early to late hybrids (Table 3 ). This could be due to the larger stems of late hybrids or to the preference of moths for latematuring germplasm. Stems also had more damage in Barrantes than in Pontevedra (Table 3). Differences among hybrids were moderate, the stem damage and ear damage followed similar patterns for these hybrids. Generally, early cultivars had more chances than late cultivars to escape the attack of pests, as noted in previous reports (Dicke and Guthrie, 1988; Malvar et al., 1993) indicting that late-maturing germplasm was more attractive to second generation moths.

Avoidance is not heritable because it depends on environmental conditions and cannot be managed by breeding, but could be useful if insect abundance can be predicted. In the early planting in Barrantes, PSB (0.33 larvae/ear) were more abundant than ECB (0.08 larvae/ear) in fresh ears, while in Pontevedra the number of larvae was similar for PSB (0.09) and ECB (0.08). Velasco et al. (1999b) found that both pests were distributed equally in fresh sweet corn ears. The average number of larvae of $M$. unipuncta (0.09) and $H$. armigera $(0.07)$ in fresh ears was similar and lower than that of PSB (0.47) or ECB (0.23). PSB larvae have been reported previously to be more abundant than ECB larvae in field corn stems (Cartea et al., 1994; Cordero et al., 1998; Malvar et al., 1993). Mean number of PSB larvae per ear was not significantly different in fresh (0.47) and dry (0.50) ears, but ECB larvae per ear were more frequent in fresh $(0.23)$ than in the dry (0.07) ears. There were significantly more PSB and ECB larvae in late ( 0.72 and 0.38 larvae per ear, respectively) than in early ( 0.19 and 0.05 larvae per ear, respectively) plantings. These results agree with previous findings (Cartea et al., 1994; Velasco et al., 1999a, 1999b). The pattern of distribution of larvae was quite stable across locations and years, but it was more constant for ECB than for PSB. Differences in stability could be attributed to the specificity of the host-pest relationships and the tolerance of the species to low temperature. Specifically, ECB and PSB are typical corn pests, but PSB is severely affected by temperatures below $0^{\circ} \mathrm{C}$ (Galichet, 1982). Mythimna unipuncta is an opportunistic pest for corn, and we have rarely found notable numbers of $H$. armigera in corn. The distribution of larvae among differently maturing hybrids did not follow a specific pattern.

PSB larvae were more frequent in fresh ears in Barrantes $(0.79$ larvae/ear) than in Pontevedra (0.14 larvae/ear). Barrantes is slightly warmer than Pontevedra and such climatic variation could explain differences in the number of PSB larvae. On the other hand, the number of ECB larvae were identical in Barrantes $(0.23)$ and Pontevedra (0.23), perhaps because the climatic differences between locations are undistinguishable for ECB due to the higher cold tolerance of this insect. Low temperatures have been proposed as the only natural control of PSB (Cordero et al., 1998; Galichet, 1982).

In conclusion, incidence of PSB was highest, followed by ECB, while $M$. unipunct $a$ and $H$. armigera cannot be considered significant pests of sweet corn in the South Atlantic European Coast. The abundance of pests increased in late plantings, while early plantings partially avoided attack. Dry ears received more damage than fresh ears and stems had more larvae than ears. Considering that ears with insect damage are not acceptable for human consumption, most of the ears can be lost due to insect attack. Also, seed production would be severely affected by PSB and ECB damage in the ear and in the stem. These data support the need of a sweet corn breeding program for pink stem borer and European corn borer resistance, paying close attention to planting dates and environments.

\section{Literature Cited}

Abedon, B.G. and W.F. Tracy. 1996. Corngrassl of maize (Zea mays L.) delays development of adult plant resistance to common rust (Puccinia sorghi Schw.) and European corn borer (Ostrinia nubilalis Hubner). J. Hered. 87:219-223.

Abel. C.A., M.A. Berhow, R.L. Wilson, B.F. Binder, and B.E. Hibbard. 2000. Evaluation of conventional resistance to European corn borer (Lepidoptera: Crambidae) and western corn rootworm (Coleoptera: Chrysomelidae) in experimental maize lines developed from a backcross breeding program. J. Econ. Entomol. 93:1814-1821.

Abel. C.A., R.L. Wilson, and J.C. Robbins. 1995. Evaluation of Peruvian 
maize for resistance to European corn borer (Lepidoptera: Pyralidae) leaf feeding and ovipositional preference. J. Econ. Entomol. 88:10441048.

Alfaro, A. 1955. Corn borers in the mid Ebro river valley. Bol. Pat. Veg. Ent. Agr. 21:1-17.

Anglade, P. 1961. Influence sur le rendement du maïs de l'infestation des tiges par la deuxième génération de la Sésamie (Sesamia nonagrioides Lef. Lép. Noctuidae). Méthodes de comparison des hybrides par infestation artificielle. Ann. Épiph. 12:413-422.

Anglade, P. 1972. Les Sesamia, p. 1389-1400. In: A.S. Balachowsky (ed.). Entomologie appliqué à l'agriculture. II, Lépidoptéres, II. Masson et Cie., Paris.

Butrón, A., R.A. Malvar, P. Velasco, M.E. Cartea, and A. Ordás. 1998. Combining abilities and reciprocal effects for maize ear resistance to pink stem borer. Maydica 43:117-122.

Cartea, M.E., R.A. Malvar, P. Revilla, A. Ordás, and A. Álvarez. 1994. Seasonal occurrence and response of maize inbred lines to pink stem borer in the northwest of Spain. Maydica 39:191-196.

Cartea, M.E., R.A. Malvar, M.I. Vales, A. Butrón, and A. Ordás. 2001. Inheritance of resistance to ear damage caused by Sesamia nonagrioides (Lepidoptera: Noctuidae) in maize. J. Econ. Entomol. 94:277-283.

Cordero, A., R.A. Malvar, A. Butrón, P. Revilla, P. Velasco, and A. Ordás. 1998. Population dynamics and life cycle of corn borers in south Atlantic European coast. Maydica 43:5-12.

Dicke, F.F. and W.D. Guthrie. 1988. The most important corn insects, p. 767-867. In: G.F. Sprague and J.W. Dudley (eds.). Corn and corn improvement. Agron. Monogr. 18. Amer. Soc. Agron., Crop Sci. Soc. Amer., and Soil Sci. Soc. Amer., Madison, Wis.

Galichet, P.F. 1982. Hibernation d'une population de Sesamia nonagrioides Lef. (Lep., Noctuidae) en France meridionale. Agronomie 2:561-566.

Gardner, J., M.P. Hoffmann, M.E. Smith, and M.G. Wright. 2001. Influence of plant age and genotype on resistance to European corn borer in sweet corn. Maydica 46:111-116.

Jarvis, J.L. 1988. Damage by European corn borer(Lepidoptera: Pyralidae) to popcorn kernels compared with damage to kernels of dent corn and sweet corn. J. Econ. Entomol. 81:1214-1216.

Kerr, E.A. 1979a. 'Goldenvee' sweet corn. Can. J. Plant Sci. 59:891892.

Kerr, E.A. 1979b. 'Tablevee' sweet corn. Can. J. Plant Sci. 59:893-894.

Kerr, E.A. 1981a. 'Northernvee' and 'Earlivee' sweet corn. Can. J. Plant Sci. 61:471-472.

Kerr, E.A. 1981b. 'Flavorvee' sweet corn. Can. J. Plant Sci. 61:487-488.

Lespès, L. and M.L. Jourdan. 1940. Observations sur la biologie de la Sésamie du maïs. Rev. Zool. Agr. Appl. 39:49-58.

Malvar, R.A., M.E. Cartea, P. Revilla, A. Ordás, A. Álvarez, and J.P. Mansilla. 1993. Sources of resistance to pink stem borer and European corn borer in maize. Maydica 38:313-319.

Melamed-Madjar, V. and S. Tam. 1980. A field survey of changes in the composition of corn borer populations in Israel. Phytoparasitica 8:201204.

SAS Institute, Inc. 1996. SAS/STAT software: Changes and enhancements through release 6.11. SAS Inst., Inc. Cary, N.C.

Singleton, W.R. 1948. Hybrid sweet corn. Conn. Agr. Expt. Sta. Bul. 518. Smith, G.M. 1955. Sweet corn, p. 441-463. In: G.F. Sprague (ed.). Corn and corn improvement. Academic Press, New York.

Tsitsipis, J.A., B. Mazomenos, and M. Alesandri. 1987. The corn stalk borer, Sesamia nonagrioides: Bioecology and control prospects. Ann. Assn. Nationale de Protection des Plantes 6:271-278.

Velasco, P., R.A. Malvar, A. Butrón, P. Revilla, and A. Ordás. 1999a. Ear feeding resistance of sweet corn inbreds to pink stem borer. J. Amer. Soc. Hort. Sci. 124:268-272.

Velasco, P., R.A. Malvar, P. Revilla, A. Butrón, and A. Ordás. 1999b. Ear resistance of sweet corn populations to Sesamia nonagrioides (Lepidoptera: Noctuidae) and Ostrinia nubilalis (Lepidoptera: Pyralidae). J. Econ. Entomol. 92:732-739. 